Article

\title{
Rainwater Harvesting for Sustainable Agriculture in High Water-Poor Areas in the West Bank, Palestine
}

\author{
Sameer Shadeed ${ }^{1, *}$, Tariq Judeh ${ }^{1}$ and Michel Riksen ${ }^{2}$ \\ 1 Water and Environmental Studies Institute, An-Najah National University, 62451 Nablus, Palestine; \\ t.judeh@najah.edu \\ 2 Soil Physics and Land Management Group, Wageningen University, 6708 Wageningen, The Netherlands; \\ Michel.Riksen@wur.nl \\ * Correspondence: sshadeed@najah.edu
}

Received: 5 December 2019; Accepted: 20 January 2020; Published: 30 January 2020

check for updates

\begin{abstract}
In most arid regions of the world, the increasing agricultural water supply-demand gap jeopardizes sustainable agricultural development and, as such, undermines local food security. In such situations, unconventional water resource practices such as agricultural rainwater harvesting (ARWH) can be potentially used to tackle agricultural water poverty (AWP). This study aims to integrate AWP and agricultural rainwater harvesting suitability (ARWHS) maps to identify locations where ARWH can be of the most benefit to the West Bank, Palestine. These maps were developed under the GIS environment. The weighted overlay summation process (WOSP), supported by the analytical hierarchy process (AHP), was utilized. Research findings of the AWP map indicate that high to very high AWP covers about $61 \%$ of the study area, whereas, the findings of the ARWHS map shows that highly suitable ARWH areas cover $65 \%$ of the total study area. Further, $31 \%$ of the study area has highly suitable sites for the implementation of proper ARWH techniques. Finally, the combined mapping between the ARWHS map and agricultural lands indicates that high to very high ARWH-suitable areas cover $53 \%$ of the rough grazing areas (62\% of the entire West Bank area). Thus, the implementation of proper ARWH techniques in such areas is seen to be a sustainable water management option for achieving agricultural sustainability and, accordingly, improved food security in the West Bank, Palestine.
\end{abstract}

Keywords: agricultural rainwater harvesting; agricultural water poverty; agricultural rainwater harvesting suitability; sustainable agriculture; GIS; West Bank (Palestine)

\section{Introduction}

Sustainable agriculture can be defined as the integration of environmental, social, and economic components to secure society's food needs [1]. Achieving food security in the face of global population growth requires that sustainable agricultural productivity be enhanced [1-3]. In arid and semi-arid regions of the world, which are home to a significant proportion of the population, water resource availability is a key factor in sustainable agriculture [2,4]; and uncertain water supply in many countries can threaten sustainable development [5]. This makes agriculture the major water-demanding sector in the world [6,7] and means that sustainable agricultural development is challenging, especially in regions where increasing water scarcity and lack of sustainable water resource management are prevailing [8]. As a result, the dominant water resource management challenge is how to satisfy the increasing agricultural water demand in order to enhance food security for the rapidly expanding world population [9].

In Palestine, which is characterized as an arid to semi-arid region, the lack of sufficient water for different uses has constrained sustainable development [10]. The situation has worsened due to 
population growth and the associated expansion of agricultural activities, imposing a remarkable burden on the limited available and uncertain water supply (e.g., groundwater). Moreover, without a doubt, the on-ground political conflict is also affecting the availability and/or accessibility of Palestinian water resources [11,12].

Agricultural water poverty (AWP) is a term that describes both quantitative and qualitative shortages in existing agricultural water resources [2]. It can be attributed to natural or human-induced causes $[13,14]$. AWP can be estimated by using the agricultural water poverty index (AWPI), which is an index that describes sustainable agricultural water management at farm-level [2]. AWPI can be affected by several factors, including availability of agricultural water, water quality and suitability for agricultural use, access to agricultural water resources and efficiency of use of supplied agricultural water [1], all of which impact food production.

Water poverty mapping is an easy and effective way to map, for instance, the spatial distribution of agricultural water-poor areas [15]. Worldwide, water poverty mapping is commonly used to evaluate both domestic and agricultural water vulnerabilities [15-18]. The use of water poverty mapping can be valuable for developing strategies to enhance water resource management and sustainable agricultural development.

Generally, agricultural water-poor areas have to consider new and/or unconventional and sustainable sources of water. In arid and semi-arid regions, given the uncertain water supply, rainwater harvesting (RWH) can be used to safeguard water for different uses [19]. This in turn has the potential to improve the social, environmental, and economic development of an area [20,21]. In the West Bank, RWH is considered a strategic alternative to satisfy the increasing water supply-demand gap for both domestic and agricultural uses [22]. RWH can be defined in many ways; however, there is not a unified definition about this term that is commonly accepted by the scientific community. Researchers employ a wide variety of terms and definitions to describe the various methods aimed at the use of, collection, and storage of rain runoff in order to increase the availability of water for drinking, irrigation, and so on, in arid and semi-arid areas. In this way, their criterion is their own purpose and not a strict definition of the term "rainwater harvesting" [23]. It is considered an ancient practice, and is still used for domestic and agricultural purposes all over the world, particularly in arid and semi-arid regions [24,25].

In these regions, agricultural water productivity has been improved by implementing proper RWH techniques for many years [2,3,24-37]. From this, the concept of agricultural rainwater harvesting (ARWH) has developed, where the focus is to collect and use rainwater specifically to increase crop yields [3]. Depending on the efficiency of the RWH technique, ARWH can be used either to enhance soil moisture content mainly in rainfed areas (e.g., the use of terraces) or as a source of water for supplementary irrigation when there is a shortage of agricultural water supply (e.g., the use of small dams to collect runoff) [24,35]. Accordingly, agricultural rainwater harvesting suitability (ARWHS) is an approach to identify potential locations where the implementation of ARWH techniques would be possible and effective.

To date, studies have mainly looked at the suitability of locations for new RWH structures, without consideration of water poverty. Adding water poverty mapping and promoting RWH and ARWH in regions where the benefits are expected to be high, based on water poverty (e.g., where water is the limiting production factor), has the potential to improve implementation of these strategies. This paper presents an approach to combining the mapping of ARWHS and AWP in order to increase the successful implementation of RWH. This new method for RWH site selection was developed and has been applied to the West Bank (Palestine) using a GIS-based multi-criteria decision analysis (MCDA) integrated approach. The MCDA approach is commonly used in both water poverty mapping $[15,17,18,38,39]$ and RWH suitability studies [18,22,40-45], as further explained in the next section. This research will be of interest to policy makers and other potential stakeholders to identify areas where ARWH can be most effective for increasing sustainable agricultural development and food security in the West Bank, Palestine. 


\section{Materials and Methods}

\subsection{Study Area}

The West Bank (Palestine) is a typical arid to semi-arid region located in the Middle East with a total surface area of about $5860 \mathrm{~km}^{2}$. It has a total population of nearly 2.9 million, distributed over 11 governorates (see Figure 1) [46].

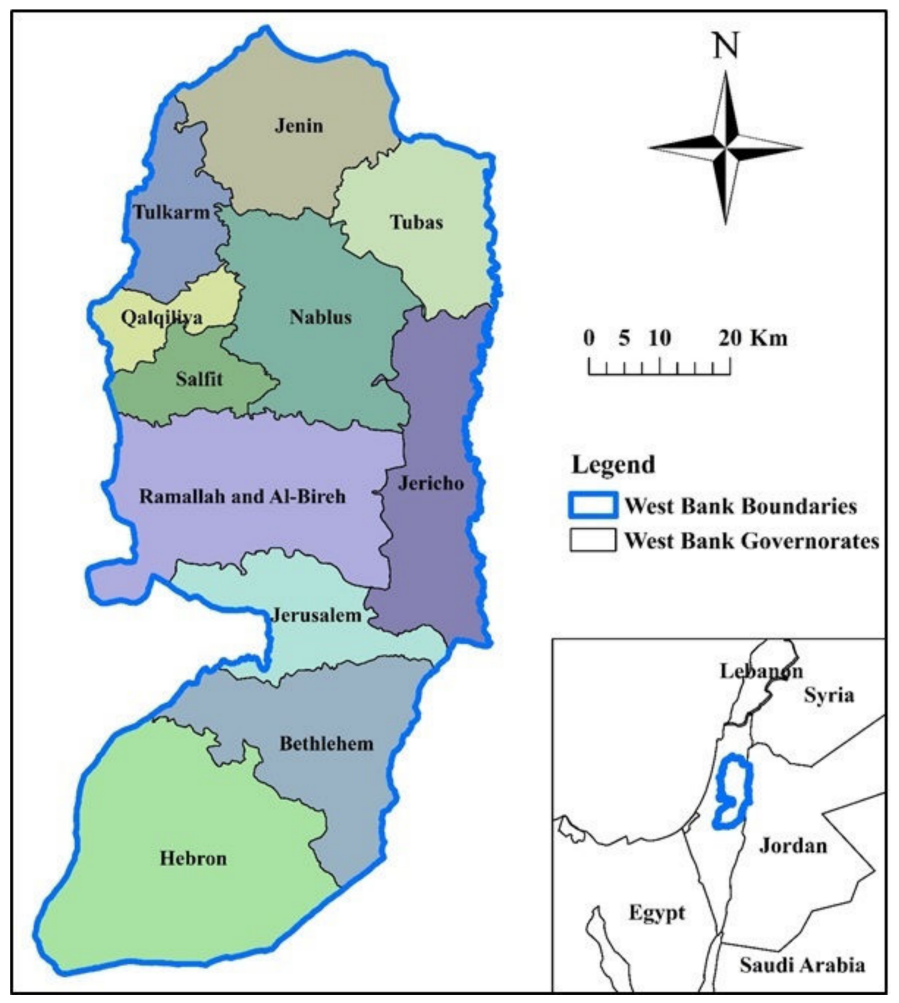

Figure 1. Location map of the West Bank, Palestine.

Elevation ranges from $1000 \mathrm{~m}$ above MSL in Hebron to $375 \mathrm{~m}$ below MSL in the proximity of the dead sea in Jericho [47]. Mediterranean climate prevails over the West Bank, which experiences high seasonal variations. Rainfall varies in time and space, with an average annual rainfall varied from a minimum of about $153 \mathrm{~mm}$ in the vicinity of the Jordan River, to a maximum of about $698 \mathrm{~mm}$ in the central mountains [47]. In general, rainfall averages decrease from west to east. Moreover, $80 \%$ of the total annual rainfall usually occurs in winter [48]. Table 1 presents the basic statistical measures of annual rainfall for some selected raingauges located in the West Bank for the period of 2007 to 2018 [49].

Table 1. Basic statistics of annual rainfall data for selected raingauges (for the period 2007-2018).

\begin{tabular}{cccccccc}
\hline \multirow{2}{*}{$\begin{array}{c}\text { Parameter } \\
(\mathbf{m m})\end{array}$} & Jenin & Tulkarm & Nablus & Ramallah & Jericho & Bethlehem & Hebron \\
\cline { 2 - 8 }$y$ & 447.2 & 559.0 & 612.7 & 605.8 & 139.3 & 477.5 & 498.3 \\
Mean & 102.9 & 209.6 & 136.0 & 120.6 & 30.2 & 62.7 & 117.2 \\
Standard & & 365.5 & 360.8 & 476.4 & 99.0 & 366.7 & 375.5 \\
deviation & 284.8 & 742.5 & 805.9 & 860.8 & 200.5 & 553.3 & 661.4 \\
Minimum & 593.1 & 377.0 & 445.1 & 384.4 & 101.5 & 186.6 & 285.9 \\
Maximum & 308.3 & & & & & & \\
Range & & & & &
\end{tabular}


From Table 1, basic statistics are obviously varying between the different stations. For instance, the standard deviation and the range indicate the spatial variability of annual rainfall and hence denote how vulnerable the rainfall is in terms of its persistence as a reliable replenishing water source.

In the West Bank, the landuse map is categorized into rough grazing/subsistence farming $(61.7 \%)$, arable land $(14.3 \%)$, irrigated farming $(2.6 \%)$, permanent crops $(14.3 \%)$ built-up areas $(5 \%)$, woodland/forest $(0.7 \%)$, and Israeli settlements (1.4\%) [47]. Generally, agricultural land development in the West Bank is being challenged by several factors. These are water shortage, low soil fertility, weak investment trends in agricultural land, poor financial resources, and high risk [50]. Of these factors, water shortage seems to be the most challenging. Hence, rainfed agriculture prevails in most of the West Bank areas. Based on the irrigated areas (open fields and greenhouses) in 2015, the agricultural water supply-demand gap for all crops in the West Bank was about 47 MCM [50].

However, the water supply in the West Bank is uncertain and does not meet the increasing water demand for agriculture. The local water (Palestinian groundwater wells and springs) and the purchased water from Mekorot (Israeli water company) are considered as the main water sources for different uses in the West Bank. To overcome water shortage, Palestinians have to look into the use of non-conventional water resources (e.g., RWH). RWH is considered as one of the strategic water resources available for different uses, among which the agricultural one is the most demanding. No accurate figures exist about the amount of water available from on-ground implementation of different ARWH techniques (e.g., earth check dams, on farm ponds) for agricultural use. However, the number is rounded to about $2.5 \mathrm{MCM}$ [51].

\subsection{Methodology}

In Figure 2, the general methodological framework applied in this study is illustrated. The research approach started by developing both AWP and ARWHS maps. Five driving factors-access, capacity, environment, resource and use-are used to determine the AWPI, as described by Gould and Nissen-Petersen [52]. Table 2 shows the seven dominant criteria that represent these five key factors for the West Bank case study. The majority of the data for these criteria were only available at governorate level (course resolution) at the Palestinian Central Bureau of Statistics (PCBS), Palestinian Water Authority (PWA), Ministry of Agriculture (MoA), and Ministry of Local Government (MoLG).

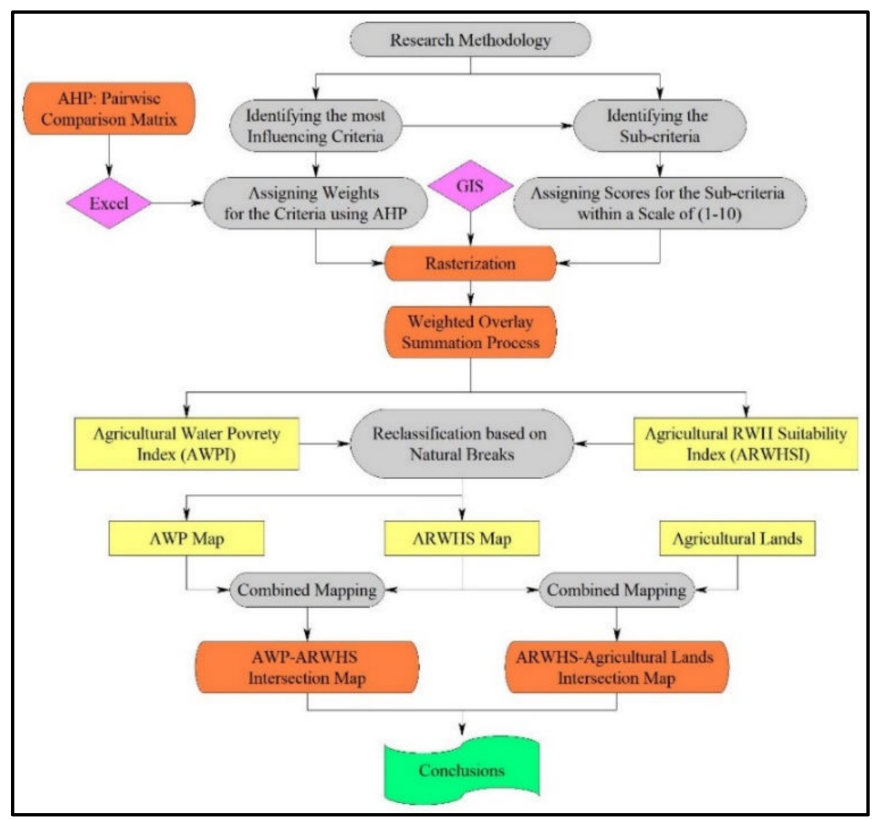

Figure 2. Research methodology. 
Table 2. Agricultural water poverty index (AWPI) key components and the associated criteria for the West Bank case study.

\begin{tabular}{cll}
\hline Key Components & & \multicolumn{1}{c}{ Criteria } \\
\hline Access & $\bullet$ & Agricultural access (Total Irrigated/(Irrigated + Irrigable)) (AA) \\
\hline \multirow{2}{*}{ Capacity } & $\bullet$ & Citizens above poverty line (CAPL) \\
\cline { 2 - 3 } & $\bullet$ & Illiteracy (I) \\
\cline { 2 - 3 } & $\bullet$ & Agricultural extension (engineers per 100 $\mathrm{km}^{2}$ of agricultural areas, AE) \\
\hline Environment & $\bullet$ & Electrical conductivity value (EC) \\
\hline Resources & $\bullet$ & Agricultural resources (agricultural water available per irrigated areas $\left.\mathrm{m}^{3} / \mathrm{ha}, \mathrm{AR}\right)$ \\
\hline Use & $\bullet$ & Irrigated areas to governorate area (IATGA) \\
\hline
\end{tabular}

For the mapping of ARWHS in the West Bank, criteria identified as most influencing were rainfall (the long term annual areal average, R), curve number (CN), land use (LU), surface slope (SS), soil texture (ST), evapotranspiration (ET), and distance from drainage network (DDN). The R and ET were obtained from the available measurements of the weather stations/rain-gauges [49]. The CN map was developed and available for the entire West Bank [53]. The LU and ST maps and digital elevation model (DEM) available at the MoLG GIS-database were used. The SS layer was produced from the available model (DEM). Given the drainage network from the DEM, the DDN factor was obtained.

To assign weights for the different criteria (layers), the AHP pairwise comparison matrix, as described by Saaty [54], was used. Tables 3 and 4 show the preference values for, respectively, the AWP and ARWHS indices.

Table 3. Analytical hierarchy process (AHP) pairwise comparison matrix for AWP index for the West Bank case study.

\begin{tabular}{ccccccccc}
\hline Criteria & AA & CAPL & I & AE & EC & AR & IATGA & Weight \\
\hline AA & 1.00 & 5.00 & 7.00 & 3.00 & 0.50 & 0.33 & 2.00 & 0.19 \\
CAPL & 0.20 & 1.00 & 2.00 & 0.50 & 0.17 & 0.14 & 0.33 & 0.04 \\
I & 0.14 & 0.50 & 1.00 & 0.33 & 0.13 & 0.11 & 0.20 & 0.03 \\
AE & 0.33 & 2.00 & 3.00 & 1.00 & 0.25 & 0.20 & 0.50 & 0.07 \\
EC & 2.00 & 6.00 & 8.00 & 4.00 & 1.00 & 0.50 & 3.00 & 0.24 \\
AR & 3.00 & 7.00 & 9.00 & 5.00 & 2.00 & 1.00 & 4.00 & 0.31 \\
IATGA & 0.50 & 2.00 & 5.00 & 2.00 & 0.33 & 0.25 & 1.00 & 0.12 \\
\hline
\end{tabular}

Table 4. AHP pairwise comparison matrix for agricultural rainwater harvesting suitability (ARWHS) index for the West Bank case study.

\begin{tabular}{ccccccccc}
\hline Criteria & $\mathbf{R}$ & $\mathbf{C N}$ & LU & SS & ST & ET & DDN & Weight \\
\hline R & 1.00 & 2.00 & 2.50 & 2.50 & 3.00 & 3.50 & 4.00 & 0.28 \\
CN & 0.50 & 1.00 & 2.00 & 2.00 & 2.50 & 2.50 & 3.00 & 0.21 \\
LU & 0.40 & 0.50 & 1.00 & 1.50 & 2.00 & 2.50 & 2.50 & 0.16 \\
SS & 0.40 & 0.50 & 0.67 & 1.00 & 1.50 & 2.00 & 2.00 & 0.12 \\
ST & 0.33 & 0.40 & 0.50 & 0.67 & 1.00 & 1.50 & 2.00 & 0.10 \\
ET & 0.29 & 0.40 & 0.40 & 0.50 & 0.67 & 1.00 & 1.50 & 0.07 \\
DDN & 0.25 & 0.33 & 0.40 & 0.50 & 0.50 & 0.67 & 1.00 & 0.06 \\
\hline
\end{tabular}

The consistency of both matrices was checked by calculating the consistency ratio, $C R$, using the following equations [54]:

$$
C R=\frac{C I}{R I}
$$




$$
C I=\frac{\lambda-n}{n-1}
$$

where $C I$ is the consistency index, $R I$ is a random consistency index, $\lambda$ is a normalized principal eigenvector, and $n$ is a number of constraints (criteria).

The estimated $C R$ values are 0.03 and 0.015 for AWP and ARWHS matrices, respectively. This indicates that both matrices are consistent, given the rule that the $C R$ value should be smaller or equal to $0.1[54,55]$.

Each of the (layers) criteria used in the AWP and ARWHS maps were classified into five value classes, each of them were assigned a score from 1 to 10 (see Tables 5 and 6) based on local expert experience sustained by several studies from the literature. As such, AWP and ARWHS optimal values (e.g., high suitable conditions) are represented by scores that are close to 10 . After rasterization $(100 \times 100 \mathrm{~m}$ cell size) of the different criteria (layers) based on their value sub classes, scores were handled by GIS (ArcMap 10.3 of ESRI) (see Figures 3 and 4).

Table 5. AWP scores assigned for the sub-criteria for the West Bank case study.

\begin{tabular}{|c|c|c|c|}
\hline$\#$ & Criteria & Value Classes & Suitability Score * \\
\hline \multirow{5}{*}{1} & \multirow{5}{*}{ AA (\%) } & $0-20$ & 10 \\
\hline & & $21-40$ & 8 \\
\hline & & $41-60$ & 6 \\
\hline & & $61-80$ & 4 \\
\hline & & 81-100 & 2 \\
\hline \multirow{5}{*}{2} & \multirow{5}{*}{ CAPL $(\%)$} & $65.1-72$ & 9 \\
\hline & & $72.1-79$ & 7 \\
\hline & & $79.1-86$ & 5 \\
\hline & & $86.1-93$ & 3 \\
\hline & & $93.1-100$ & 1 \\
\hline \multirow{5}{*}{3} & \multirow{5}{*}{$\mathrm{I}(\%)$} & $4.5-5.0$ & 6 \\
\hline & & $3.9-4.4$ & 5 \\
\hline & & $3.3-3.8$ & 4 \\
\hline & & $2.7-3.2$ & 3 \\
\hline & & $2.1-2.6$ & 2 \\
\hline \multirow{3}{*}{4} & \multirow{3}{*}{$\begin{array}{c}\text { AE (Agricultural } \\
\text { Engineer/100 km²) }\end{array}$} & $<40$ & 8 \\
\hline & & $40-80$ & 5 \\
\hline & & $>80$ & 2 \\
\hline \multirow{5}{*}{5} & \multirow{5}{*}{$\mathrm{EC}(\mu \mathrm{S} / \mathrm{cm})$} & $>1100$ & 10 \\
\hline & & 951-1100 & 8 \\
\hline & & $801-950$ & 6 \\
\hline & & $651-800$ & 4 \\
\hline & & $\leq 650$ & 2 \\
\hline \multirow{5}{*}{6} & \multirow{5}{*}{$\operatorname{AR}\left(m^{3} / h a\right)$} & $\leq 2000$ & 9 \\
\hline & & $2001-4000$ & 7 \\
\hline & & $4001-6000$ & 5 \\
\hline & & $6001-8000$ & 3 \\
\hline & & $>8000$ & 1 \\
\hline \multirow{5}{*}{7} & \multirow{5}{*}{ IATGA (\%) } & $<2$ & 10 \\
\hline & & $2-3.9$ & 8 \\
\hline & & $4-5.9$ & 6 \\
\hline & & $6-7.9$ & 4 \\
\hline & & $\geq 8$ & 2 \\
\hline
\end{tabular}

${ }^{*}$ Low score $=$ low suitability and high score $=$ high suitability. 
Table 6. ARWHS scores assigned for the value classes for the West Bank case study.

\begin{tabular}{|c|c|c|c|}
\hline \# & Criteria & Value Classes & Suitability Score * \\
\hline \multirow{5}{*}{1} & \multirow{5}{*}{ R (mm/year) } & $153.0-262.1$ & 1 \\
\hline & & $262.2-371.3$ & 3 \\
\hline & & $371.4-480.5$ & 5 \\
\hline & & $480.6-589.7$ & 7 \\
\hline & & $589.8-698.9$ & 9 \\
\hline \multirow{5}{*}{2} & \multirow{5}{*}{$\mathrm{CN}$} & $\leq 50$ & 1 \\
\hline & & $51-60$ & 3 \\
\hline & & $61-70$ & 5 \\
\hline & & $71-80$ & 7 \\
\hline & & $>80$ & 9 \\
\hline \multirow{7}{*}{3} & \multirow{7}{*}{ LU } & $\begin{array}{c}\text { Built-up } \\
\text { areas/Israeli } \\
\text { settlements }\end{array}$ & 1 \\
\hline & & $\begin{array}{c}\text { Woodland/Forest } \\
\text { Rough }\end{array}$ & 4 \\
\hline & & $\begin{array}{c}\text { grazing/Subsistence } \\
\text { farming }\end{array}$ & 5 \\
\hline & & Irrigated farming & \\
\hline & & $\begin{array}{l}\text { (supporting } \\
\text { vegetables) }\end{array}$ & 6 \\
\hline & & $\begin{array}{c}\text { Permanent crops } \\
\text { (grapes, olives, } \\
\text { citrus, etc.) }\end{array}$ & 8 \\
\hline & & $\begin{array}{c}\text { Arable land } \\
\text { (supporting grains) }\end{array}$ & 9 \\
\hline \multirow{5}{*}{4} & \multirow{5}{*}{ SS (Degree) } & $\geq 24.0$ & 1 \\
\hline & & $18-23.9$ & 3 \\
\hline & & $12-17.9$ & 5 \\
\hline & & 6-11.9 & 7 \\
\hline & & $\leq 5.9$ & 9 \\
\hline \multirow{5}{*}{5} & \multirow{5}{*}{ ST } & Bare rocks & 1 \\
\hline & & Sandy loam & 3 \\
\hline & & Loamy & 5 \\
\hline & & Clay loam & 7 \\
\hline & & Clay & 9 \\
\hline \multirow{5}{*}{6} & \multirow{5}{*}{$\mathrm{ET}(\mathrm{mm} /$ year $)$} & 1944-2097 & 1 \\
\hline & & 1790-1943 & 3 \\
\hline & & $1636-1789$ & 5 \\
\hline & & $1482-1635$ & 7 \\
\hline & & $1328-1481$ & 9 \\
\hline \multirow{5}{*}{7} & \multirow{5}{*}{$\mathrm{DDN}(\mathrm{m})$} & $\geq 3000$ & 1 \\
\hline & & 2000-2999 & 3 \\
\hline & & 1000-1999 & 5 \\
\hline & & 500-999 & 7 \\
\hline & & $<500$ & 9 \\
\hline
\end{tabular}

${ }^{*}$ Low score $=$ low suitability and high score $=$ high suitability. 


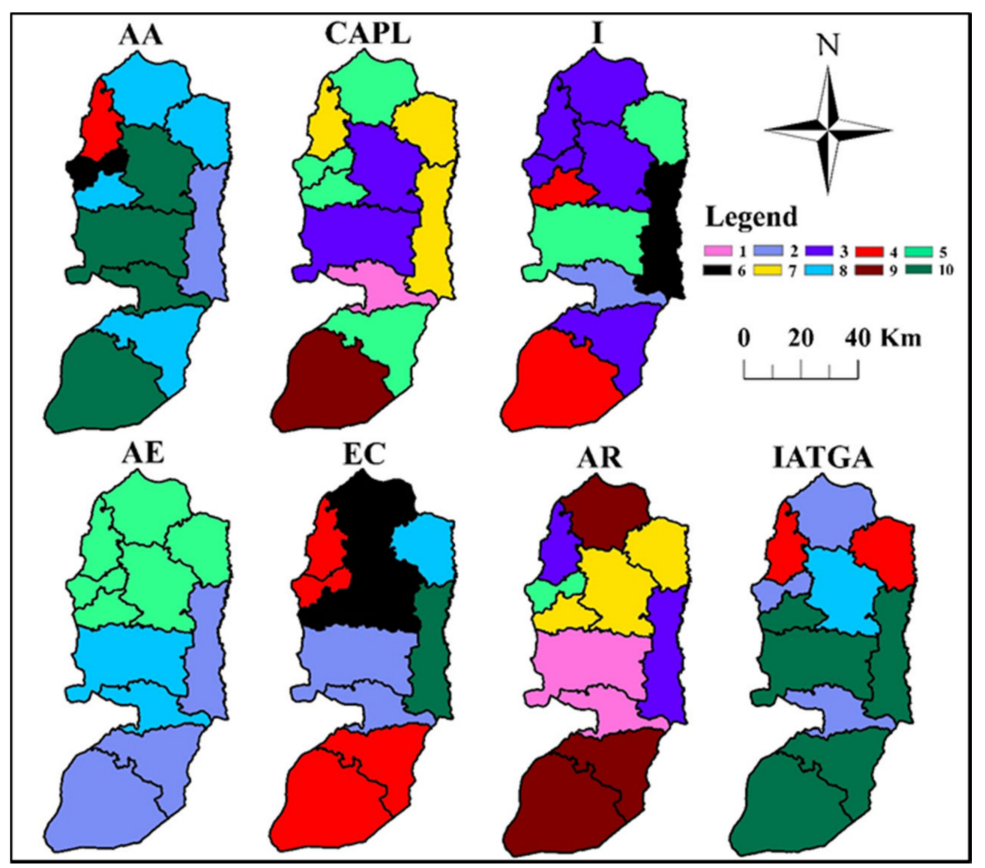

Figure 3. The score rasters of the 12 AWP criteria for the West Bank case study.

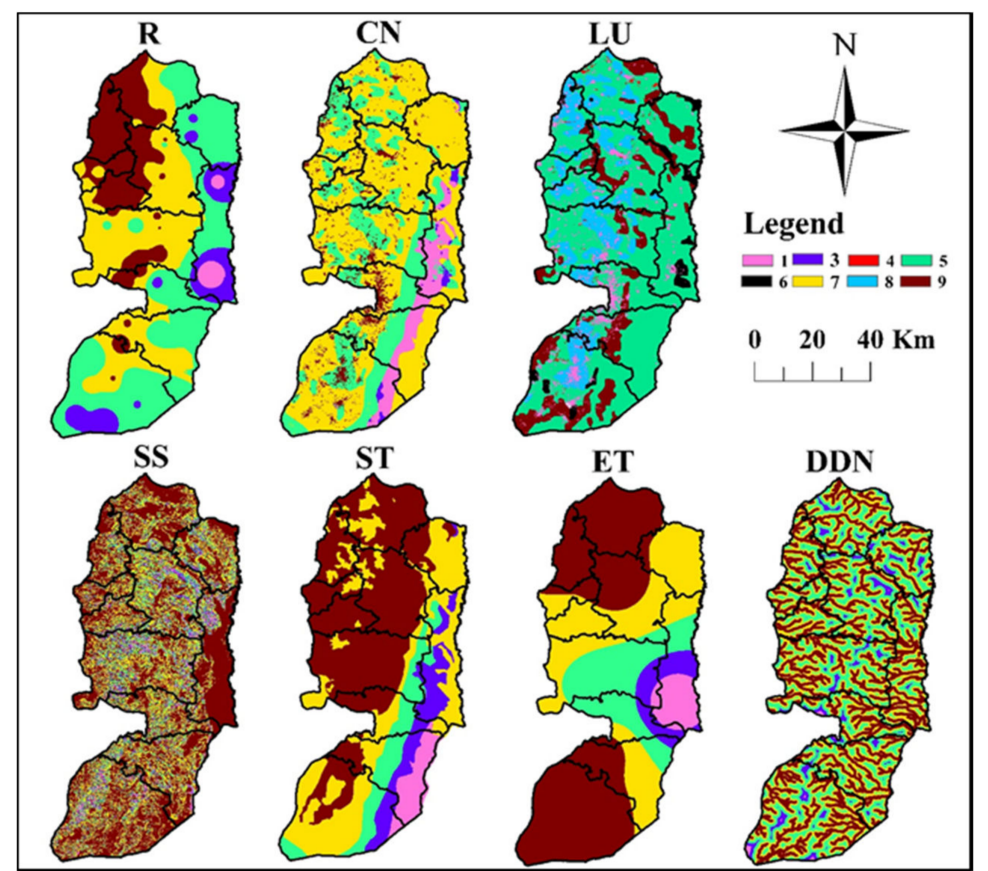

Figure 4. The score rasters of the seven ARWHS criteria for the West Bank case study.

GIS is employed to estimate the agricultural water poverty index $(A W P I)$ and the agricultural rainwater harvesting suitability index (ARWHSI) through the use of WOSP [56] for the different selected layers by aggregating the weighted cell values together. Each input layer is multiplied by its assigned weight and the results are summed as

$$
(A W P I \text { or } A R W H S I)_{j}=\sum_{i=1}^{n} W_{i} \times S_{i j}
$$


where AWPIj ARWHSIj is the final cell index, Wi is a normalized weight $\left(\sum W i=1\right)$, Sij is the score of the $i$ th cell with respect to the $j$ th layer, and $n$ is the number of cells in each $j$ th layer [57].

Finally, combined mapping between (1) AWP and ARWHS maps, and (2) ARWHS map and agricultural lands was conducted to identify potential sites for the implementation of proper ARWH techniques.

\section{Results and Discussion}

\subsection{AWP Map}

The developed AWP map for the study area is illustrated in Figure 5. Based on the natural breaks approach (under the GIS), the West Bank can be divided into five categories of water poverty. These are very low, low, moderate, high, and very high.

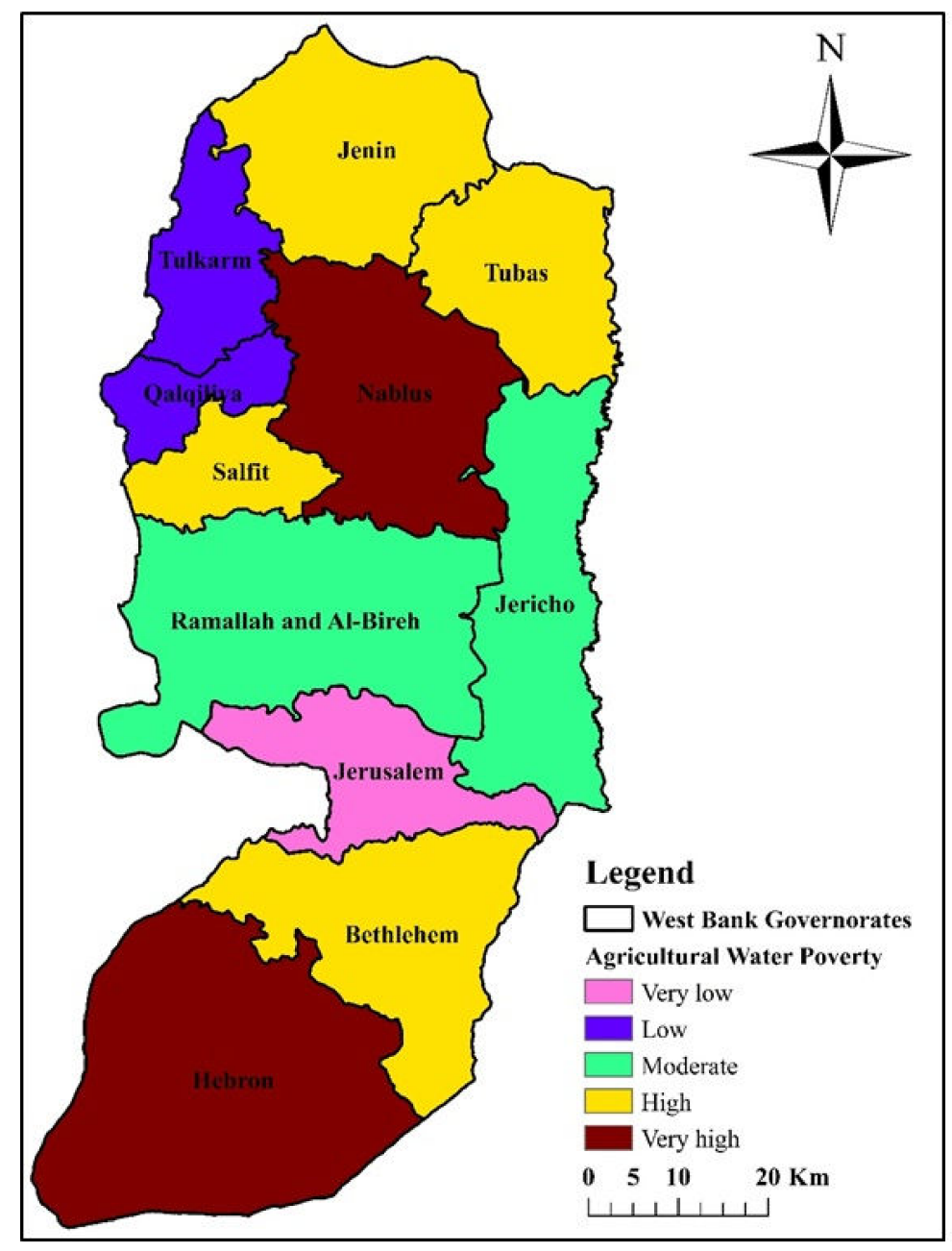

Figure 5. AWP map for the West Bank case study.

From Figure 5, it is found that the six out of 11 governorates in the West Bank are under high to very high AWP. These are Hebron, Bethlehem, Salfit, Nablus, Tubas, and Jenin. Contrary, Qaqiliya and Tulkarm governorates are under low AWP, whereas, Jerusalem governorate has the lowest AWP. The areas (\%) of the five AWP categories in the study area are tabulated in Table 7. 
Table 7. Areas (\%) of the five AWP categories in the West Bank case study.

\begin{tabular}{|c|c|c|c|c|c|}
\hline AWP Class & Very Low & Low & Moderate & High & Very High \\
\hline Area $(\%)^{1}$ & 6 & 8 & 25 & 32 & 29 \\
\hline
\end{tabular}

Results shown in Table 7 indicate that water-poor areas cover $61 \%$ of the West Bank, where 1.75 million (61\% of Palestinians) are living. This, in turn, will impact the sustainability of agricultural food supply from irrigated areas (e.g., tomatoes, cucumbers, and potatoes) and rainfed areas (e.g., olives) in most of the Palestine governorates. This argues the necessity to apply more sustainable water supply options (e.g., ARWH techniques) in the high water-poor areas to partially fulfill agricultural water needs therein.

\subsection{ARWHS Map}

In Figure 6, the developed ARWHS map for the study area is illustrated. As for the AWP map, the ARWHS map was divided into five suitability categories: very low, low, moderate, high, and very high. The ARWHS map shows that the very high categorized areas are mostly located in the north-western parts of the study area, with some little areas that are located in the middle parts. In contrast, the very low to low areas are concentrated in the eastern areas, mainly in Jericho and Bethlehem governorates. The areas (\%) of the five ARWHS categories in the different West Bank governorates are presented in Figure 7.

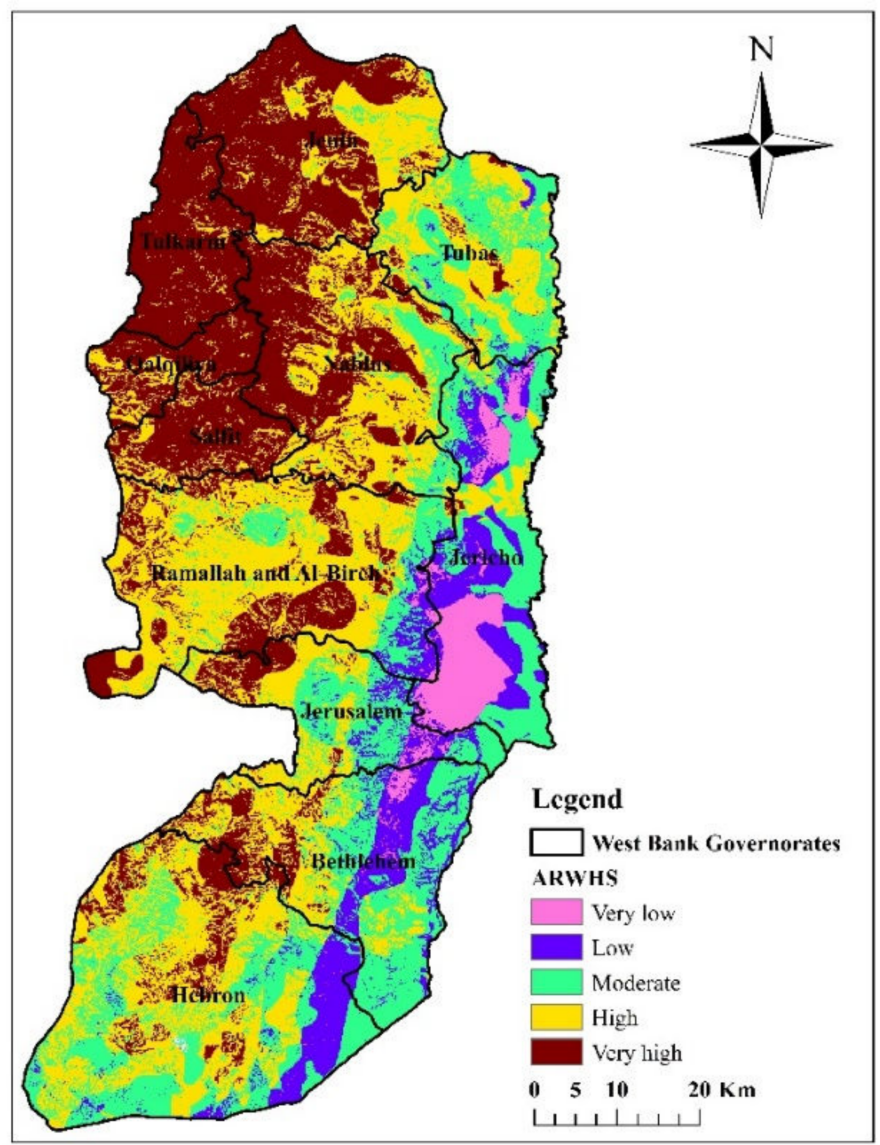

Figure 6. ARWHS map for the West Bank case study. 


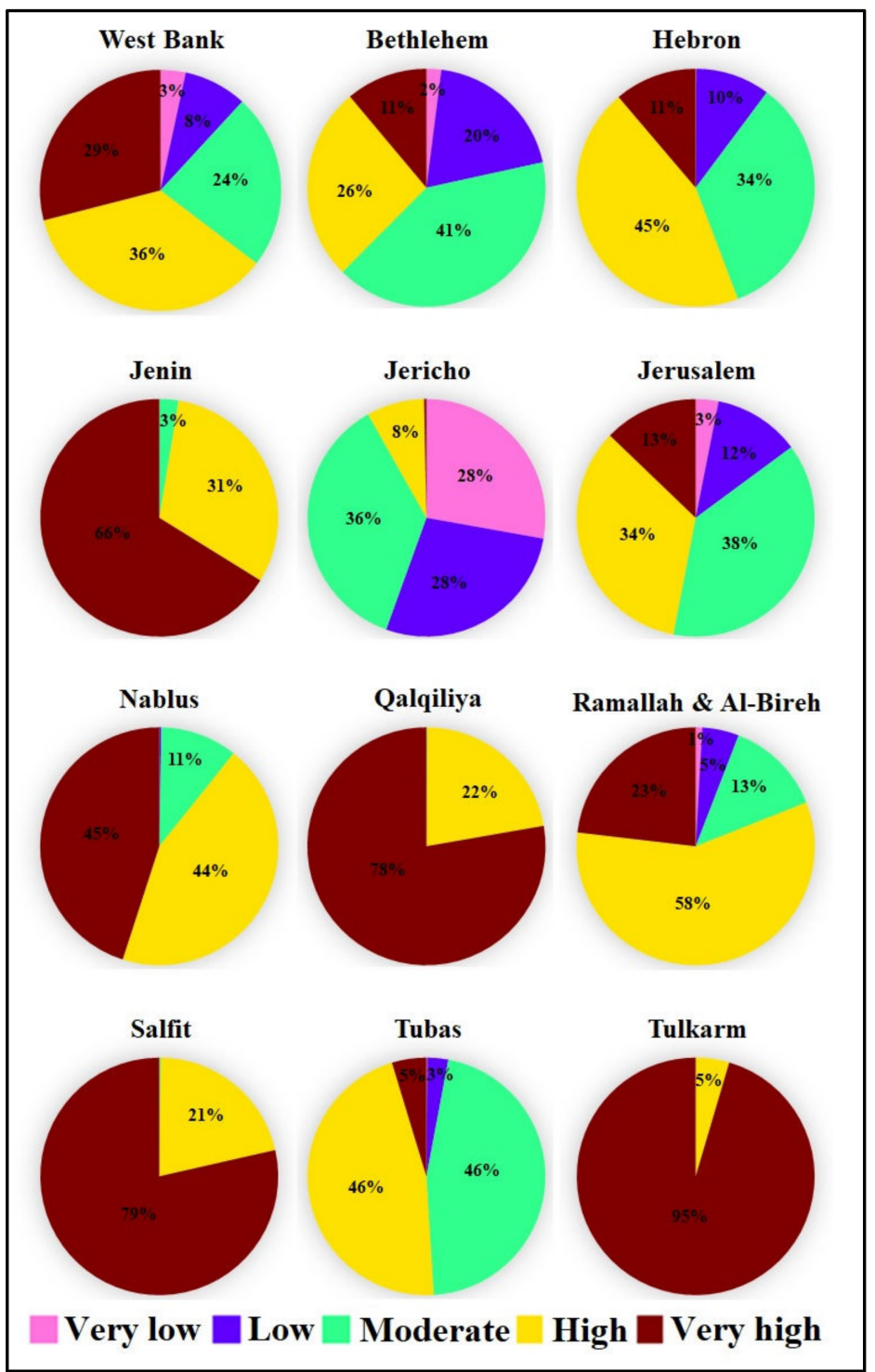

Figure 7. Areas (\%) of the five ARWHS categories in the West Bank governorates.

It is noticed from Figure 7 that about $65 \%$ of the West Bank is categorized as high to very high suitable areas for ARWH interventions. It is also obvious that the high to very high ARWH-suitable areas prevail (66\%-95\%) in the governorates of Jenin, Qalqiliya, Salfit, and Tulkarm. As such, the implementation of proper ARWH techniques would possibly satisfy the increasing agricultural water supply-demand gap and accordingly enhance food security in the West Bank.

\subsection{Combined Mapping}

\subsubsection{AWP-ARWHS Intersection Map}

The obtained AWP and ARWHS maps have compelled the dire need to pinpoint potential sites (hotspot areas) where the implementation of proper ARWH techniques would be a viable option to overcome water shortage, mainly in the high to very high agriculturally water-poor areas. Hence, GIS was utilized to combine (intersect) the maps of AWP and ARWHS. The emphasis was on the four intersection zones shown in Figure 8. Results indicate that potential sites cover about 40\% of the West Bank and are mainly located in the northern governorates of Jenin, Tubas, Nablus, and Salfit and southern governorates of Bethlehem and Hebron. 


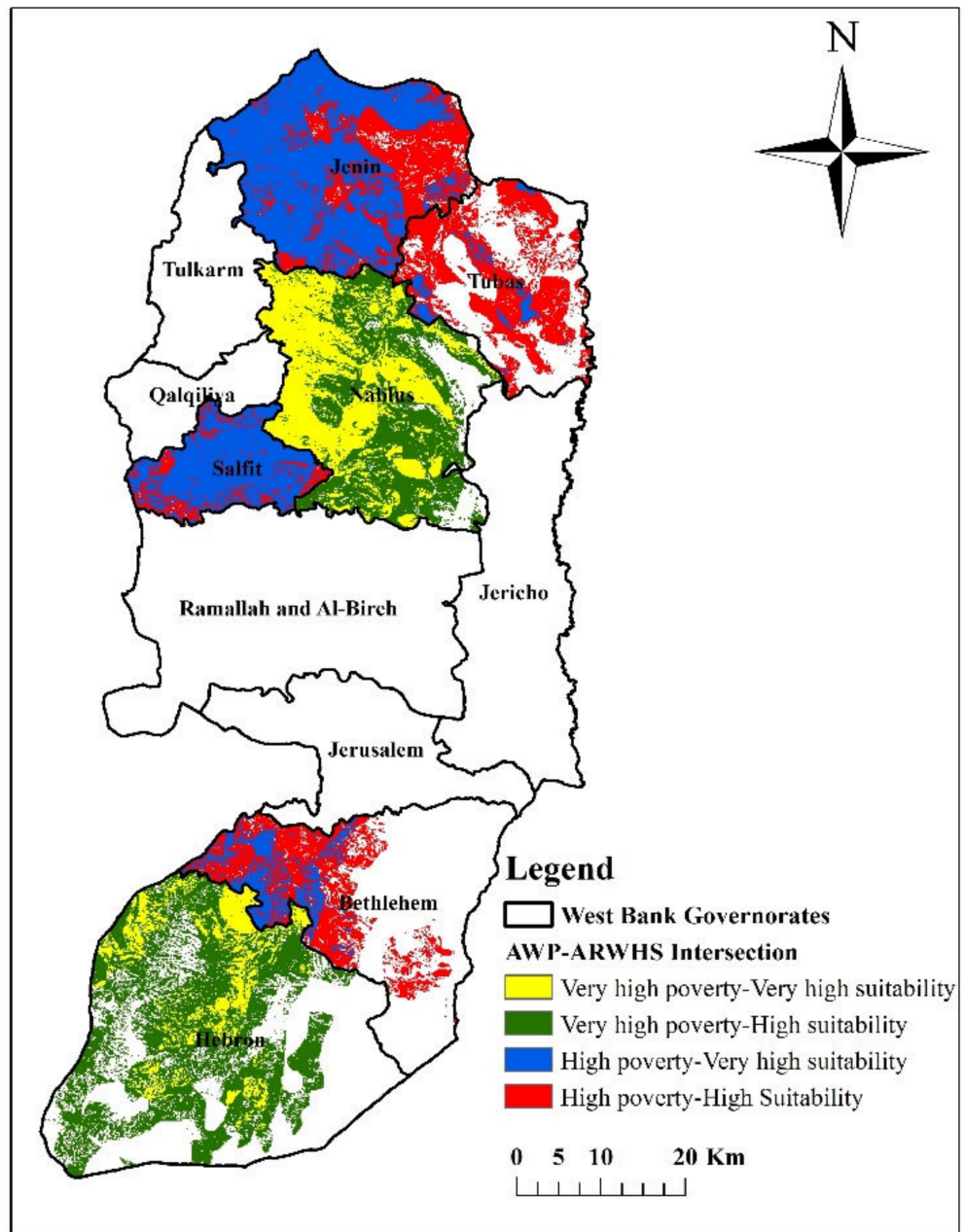

Figure 8. AWP-ARWH intersection map for the West Bank case study.

\subsubsection{ARWHS-Agricultural Lands Intersection Map}

Under the uncertain agricultural water supply, the agricultural water supply-demand gap (48 MCM) will potentially be increased. Hence, the adoption of ARWH techniques in selected sites is seen to be a strategic option for sustainable agricultural development in the West Bank. To do so, the developed ARWHS map was intersected with the agricultural lands map (see Figure 9).

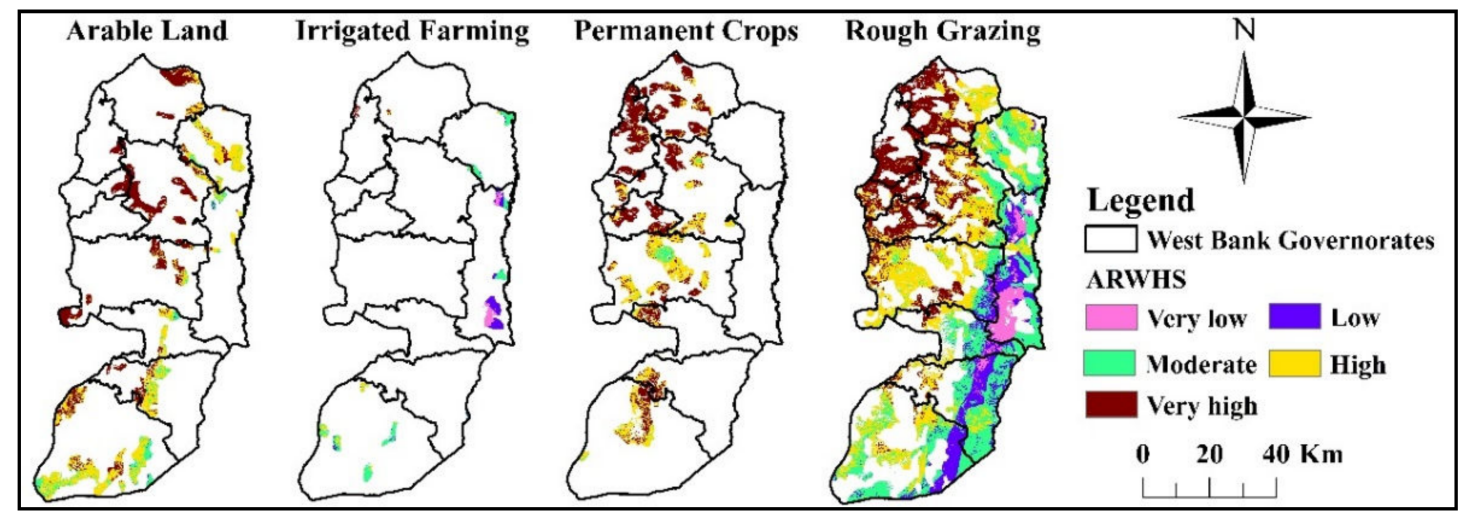

Figure 9. ARWHS-agricultural lands intersection map for the West Bank case study. 
The figure illustrates that rough grazing covers most of the West Banks area. The percentage of ARWH suitability classes for the different agricultural lands is presented in Table 8.

Table 8. Percentage of the ARWH suitability classes for the different types of land use in the West Bank.

\begin{tabular}{lcccccc}
\hline \multirow{2}{*}{ Land Use Class } & \multirow{2}{*}{ Area (\%) } & $\mathbf{1}$ & \multicolumn{5}{c}{ ARWH Suitability (\%) } \\
\cline { 3 - 7 } & & Very High & High & Moderate & Low & Very Low \\
\hline Arable Land (supporting grains) & 14.3 & 14.3 & 46.2 & 12.2 & 0.6 & 0.0 \\
\hline Irrigated Farming (supporting vegetables) & 2.6 & 2.6 & 10.1 & 46.8 & 25.9 & 13.5 \\
\hline Permanent Crops (grapes, olives, citrus, etc.) & 14.3 & 14.3 & 38.6 & 3.7 & 0.0 & 0.0 \\
\hline Rough Grazing/Subsistence Farming & 61.7 & 61.7 & 32.2 & 30.3 & 12.2 & 4.5 \\
\hline
\end{tabular}

${ }^{1}$ Area of each land use category to the total West Bank area.

Results presented in Table 8 demonstrate that areas of arable land and permanent crops $(28.6 \%$ of the West Bank area) are mostly covered by high to very high ARWH-suitable areas ( $87 \%$ to $96 \%$ ). Further, high to very high ARWH-suitable areas cover $53 \%$ of the rough grazing areas, which accounts for $62 \%$ of the total West Bank area. Thus, there is an urgent need to invest in the implementation of proper ARWH techniques, mainly in the these areas, in order to alleviate water shortage for agricultural uses.

\section{Conclusions}

The aim of this research is to better identify locations for successful implementation of ARWH techniques. As such, the used approach was to combine the identification of locations with high to very high agricultural water shortage with suitability mapping for RWH. Research findings show that $61 \%$ of the total West Bank is classified as high to very high agriculture water-poor areas. The ARWHS map indicates that high to very high suitable areas are concentrated in the north-western parts of the West Bank, with some small areas that are located in the middle and southern parts. The high to very high AWP and ARWHS areas formed more than $40 \%$ of the West Bank. Moreover, $53 \%$ of the rough grazing areas (62\% of the entire West Bank area) are characterized as high to very high ARWH-suitable areas.

GIS-based MCDA was utilized for the mapping of AWP and ARWHS for the case study of the West Bank, Palestine. This approach is of high value to identify the suitable sites where the implementation of proper ARWH techniques is deem to be a strategic option to enhance water availability for agricultural uses, mainly in high agricultural water-poor areas. The MCDA approach was utilized to study the importance of influencing criteria (layers) in the mapping of AWP and ARWHS. Normalized weights were assigned for different layers using the AHP pairwise comparison matrix approach. The combined mapping used in this research can be applied elsewhere once the thematic layers (criteria) become available. Further, it helps identify potential sites where the implementation of ARWH techniques can successfully satisfy water needs, especially in agricultural water-poor areas.

However, the used approach has some shortcomings. The accuracy of the obtained maps is greatly dependent on the resolution and ground alterations of the used thematic GIS layers, and the subjectivity and judgment in assigning the scores of the different input layers (criteria). The social, economic, and environmental limitations were not studied. Despite of these drawbacks, we think that our novel approach managed to provide insight toward the identification, by means of the AWP map, of high agricultural water-poor areas with a high potential for successful implementation of ARWH techniques based on the ARWHS map.

In view of the fact that the MCDA entails subjectivity in assigning the weights and the scores of different input layers, it is recommended that an uncertainty assessment be conducted by altering the weights and scores and, thereafter, the impacts on the mapping of both AWP and ARWHS be assessed. Further research is recommended to identify proper sites based on site selection criteria (including social, economic, and environmental) analysis for a realistic implementation of proper 
ARWH techniques in the West Bank to best support the social, economic, and environmental aspirations of the Palestinians.

To conclude, the results of this research study can be used by key policy makers (PWA and MoA) and other potential stakeholders to prioritize areas where ARWH can be most effective to improve sustainable agricultural development and food security in the West Bank, Palestine.

Author Contributions: Conceptualization, S.S.; methodology, S.S. and T.J.; T.J. and S.S.; formal analysis, S.S.; writing — original draft preparation, S.S.; writing — review and editing, M.R.; project administration, S.S. All authors have read and agreed to the published version of the manuscript.

Funding: This research study was funded by the Netherlands Representative Office (NRO) in Ramallah, Palestine under the grant of the Palestinian Dutch Academic Cooperation Program on Water (PADUCO 2).

Conflicts of Interest: The authors declare no conflict of interest.

\section{References}

1. Gafsi, M.; Legagneux, B.; Nguyen, G.; Robin, P. Towards sustainable farming systems: Effectiveness and deficiency of the French procedure of sustainable agriculture. Agric. Syst. 2006, 90, 226-242. [CrossRef]

2. Forouzani, M.; Karami, E. Agricultural water poverty index and sustainability. Agron. Sustain. Dev. 2011, 31, 415-432. [CrossRef]

3. Velasco-Muñoz, J.F.; Aznar-Sánchez, J.A.; Batlles-delaFuente, A.; Fidelibus, M.D. Rainwater harvesting for agricultural irrigation: An analysis of global research. Water 2019, 11, 1320. [CrossRef]

4. Damkjaer, S.; Taylor, R. The measurement of water scarcity: Defining a meaningful indicator. Ambio 2017, 46, 513-531. [CrossRef]

5. Yokwe, S. Water productivity in smallholder irrigation schemes in South Africa. Agric. Water Manag. 2009, 96, 1223-1228. [CrossRef]

6. Abalu, G.; Hassan, R. Agricultural productivity and natural resource use in Southern Africa. Food Policy 1998, 23, 477-490. [CrossRef]

7. Velasco-Muñoz, J.F.; Aznar-Sánchez, J.A.; Belmonte-Ureña, L.J.; Román-Sánchez, I.M. Sustainable water use in agriculture: A review of worldwide research. Sustainability 2018, 10, 1084. [CrossRef]

8. Hamdy, A.; Ragab, R.; Scarascia-Mugnozza, E. Coping with water scarcity: Water saving and increasing water productivity. Irrig. Drain. 2003, 52, 3-20. [CrossRef]

9. Rockström, J.; Folke, C.; Gordon, L.; Hatibu, N.; Jewitt, G.; Penning de Vries, F.; Rwehumbiza, F.; Sally, H.; Savenije, H.; Schulze, R. A watershed approach to upgrade rainfed agriculture in water scarce regions through Water System Innovations: An integrated research initiative on water for food and rural livelihoods in balance with ecosystem functions. Phys. Chem. Earth Parts A B C 2004, 29, 1109-1118. [CrossRef]

10. Palestinian Water Authority (PWA). Annual Status Report on Water Resources, Water Supply, and Wastewater in the Occupied State of Palestine; PWA: Ramallah, Palestine, 2011; p. 97.

11. Shadeed, S. Up to Date Hydrological Modeling in Arid and Semi-arid Catchment, the Case of Faria Catchment, West Bank, Palestine. Ph.D. Thesis, Faculty of Forest and Environmental Sciences, Albert-Ludwigs-Universität, Freiburg imBreisgau, Germany, 2008.

12. Judeh, T.; Haddad, M.; Özerol, G. Assessment of water governance in the West Bank, Palestine. Int. J. Glob. Environ. Issues 2017, 16, 119-134. [CrossRef]

13. Mehta, L. The manufacture of popular perceptions of scarcity: Dams and water-related narratives in Gujarat, India. World Dev. 2001, 29, 2025-2041. [CrossRef]

14. Noemdoe, S.; Jonker, L.; Swatuk, L.A. Perceptions of water scarcity: The case of Genadendal and outstations. Phys. Chem. Earth Parts A B C 2006, 31, 771-778. [CrossRef]

15. Thakur, J.; Mahesh, N.; Mohanan, A. Water poverty in upper Bagmati River Basin in Nepal. Water Sci. 2017, 31, 93-108. [CrossRef]

16. Wescoat, J.L., Jr.; Headington, L.; Theobald, R. Water and poverty in the United States. Geoforum 2007, 38, 801-814. [CrossRef]

17. Isaac, J.; Gigliol, I.; Hilal, J. Domestic Water Vulnerability Mapping in the West Bank/Occupied Palestinian Territory; Applied Research Institute: Bethlehem, Palestine, 2008; p. 24. 
18. Shadeed, S.; Judeh, T.; Almasri, M. Developing GIS-based water poverty and rainwater harvesting suitability maps for domestic use in the dead sea region (West Bank, Palestine). Hydrol. Earth Syst. Sci. 2019, 23, 1581-1592. [CrossRef]

19. Abdulrazzak, M. Water harvesting practices in selected countries of the Arabian Penisula. In Proceeding of the Conference on Water Harvesting and the Future Development, Khartoum, Sudan, 19-20 August 2003; pp. 19-20.

20. UN Environment Programme (UNEP). Rainwater Harvesting "A Lifeline for Human Well-Being"; UNEP: Stockholm, Sweden, 2009; p. 80.

21. Shadeed, S.; Lange, J. Rainwater harvesting to alleviate water scarcity under dry conditions: A case study in Faria catchment, Palestine. Water Sci. Eng. 2010, 3, 132-143.

22. Shadeed, S. Developing a GIS-based suitability map for rainwater harvesting in the West Bank, Palestine. In Proceedings of the International Conference on Environmental Education for Sustainable Development: Plugging the Hole, Palestine, Birzeit, 16-17 November 2011.

23. Yannopoulos, S.; Giannopoulou, I.; Kaiafa-Saropoulou, M. Investigation of the current situation and prospects for the development of rainwater harvesting as a tool to confront water scarcity worldwide. Water 2019, 11, 2168. [CrossRef]

24. Qadir, M.; Sharma, B.R.; Bruggeman, A.; Choukr-Allah, R.; Karajeh, F. Non-conventional water resources and opportunities for water augmentation to achieve food security in water scarce countries. Agric. Water Manag. 2007, 87, 2-22. [CrossRef]

25. Critchley, W.; Siegert, K.; Chapman, C.; Finkel, M. Water Harvesting: A Manual for the Design and Construction of Water Harvesting Schemes for Plant Production; Food and Agriculture Organization of the United Nations: Rome, Italy, 1991; p. 154.

26. Boers, T.M.; Zondervan, K.; Ben-Asher, J. Micro-catchment-water-harvesting (MCWH) for arid zone development. Agric. Water Manag. 1986, 12, 21-39. [CrossRef]

27. Bruins, H.J.; Evenari, M.; Nessler, U. Rainwater-harvesting agriculture for food production in arid zones: The challenge of the African famine. Appl. Geogr. 1986, 6, 13-32. [CrossRef]

28. Abu-Awwad, A.M.; Shatanawi, M.R. Water harvesting and infiltration in arid areas affected by surface crust: Examples from Jordan. J. Arid. Environ. 1997, 37, 443-452. [CrossRef]

29. Van Wesemael, B.; Poesen, J.; Benet, A.S.; Barrionuevo, L.C.; Puigdefábregas, J. Collection and storage of runoff from hillslopes in a semi-arid environment: Geomorphic and hydrologic aspects of the aljibe system in Almeria Province, Spain. J. Arid. Environ. 1998, 40, 1-14. [CrossRef]

30. Oweis, T.; Hachum, A.; Kijne, J. Water Harvesting and Supplemental Irrigation for Improved Water Use Efficiency in Dry Areas; International Water Management Institute: Colombo, Sri Lanka, 1999; p. 41.

31. Li, F.R.; Cook, S.; Geballe, G.T.; Burch, W.R. Rainwater harvesting agriculture: An integrated system for water management on rainfed land in China's semiarid areas. AMBIO A J. Hum. Environ. 2000, 29, 477-483. [CrossRef]

32. Li, X.Y.; Gong, J.D. Compacted microcatchments with local earth materials for rainwater harvesting in the semiarid region of China. J. Hydrol. 2002, 257, 134-144. [CrossRef]

33. Rosegrant, M.W.; Cai, X.; Cline, S.A. World Water and Food to 2025 "Dealing with Scarcity"; International Food Policy Research Institute: Washington, DC, USA, 2002; p. 338.

34. Ngigi, S.N.; Savenije, H.H.G.; Rockström, J.; Gachene, C.K. Hydro-economic evaluation of rainwater harvesting and management technologies: Farmers' investment options and risks in semi-arid Laikipia district of Kenya. J. Phys. Chem. Earth 2005, 30, 772-782. [CrossRef]

35. Oweis, T.; Hachum, A. Water harvesting and supplemental irrigation for improved water productivity of dry farming systems in West Asia and North Africa. Agric. Water Manag. 2006, 80, 57-73. [CrossRef]

36. Rockström, J.; Barron, J. Water productivity in rainfed systems: Overview of challenges and analysis of opportunities in water scarcity prone savannahs. Irrig. Sci. 2007, 25, 299-311. [CrossRef]

37. Tamaddun, K.; Kalra, A.; Ahmad, S. Potential of rooftop rainwater harvesting to meet outdoor water demand in arid regions. J. Arid Land 2018, 10, 68-83. [CrossRef]

38. Sullivan, C.; Meigh, J.; Giacomello, A.; Fediw, T.; Lawrence, P.; Samad, M.; Mlote, S.; Hutton, C.; Allan, J.; Schulze, R.; et al. The water poverty index: Development and application at the community scale. United Nations Sustain. Dev. J. 2003, 27, 189-199. [CrossRef] 
39. Van der Vyver, C.; Jordaan, D. Water Poverty Mapping and Its Role in Assisting Water Management; IBIMA: Madrid, Spain, 2011; Volume 2011, p. 13.

40. Galarza-Molina, S.; Torres, A.; Moura, P.; Lara-Borrero, J. CRIDE: A case study in multi-criteria analysis for decision-making support in rainwater harvesting. Int. J. Inf. Tech. Decis. Mak. 2015, 14, 43-67. [CrossRef]

41. Hussein, F.; Shariff, R. Selection of rainwater harvesting sites by using remote sensing and GIS techniques: A case study of Kirkuk, Iraq. J. Teknol. 2015, 76, 75-81.

42. Singh, L.; Jha, M.; Chowdary, V. Multi-criteria analysis and GIS modelling for identifying prospective water harvesting and artificial recharge sites for sustainable water supply. J. Clean. Prod. 2016, 142, 1436-1456. [CrossRef]

43. Singhai, A.; Das, S.; Kadam, A.; Shukla, J.; Bundela, D.; Kalashetty, M. GIS-based multi-criteria approach for identification of rainwater harvesting zones in upper Betwa sub-basin of Madhya Pradesh, India. Environ. Dev. Sustain. 2017, 17, 777-797. [CrossRef]

44. Jha, M.; Chowdary, V.; Kulkarni, Y.; Mal, B. Rainwater harvesting planning using geospatial techniques and multicriteria decision analysis. Resour. Conserv. Recycl. 2014, 83, 96-111. [CrossRef]

45. Adham, A.; Khamis, N.; Abed, R.; Abdeladhim, M.; Wesseling, J.; Riksen, M.; Fleskens, L.; Usama Karim, U.; Ritsema, C. A GIS-based approach for identifying potential sites for harvesting rainwater in the Western Desert of Iraq. Int. Soil Water Conserv. Res. 2018, 6, 297-304. [CrossRef]

46. Palestinian Central Bureau of Statistics (PCBS). Preliminary Census Results; PCBS: Ramallah, Palestine, 2017 ; p. 82.

47. Geomolg. Available online: https://data-molg.opendata.arcgis.com/datasets (accessed on 12 February 2019).

48. Shadeed, S. Spatio-temporal drought analysis in arid and semi-arid regions: A case study from Palestine. Arab. J. Sci. Eng. 2012, 38, 2303-2313. [CrossRef]

49. Palestinian Meteorological Department. Climate Bulletin. Available online: http://www.pmd.ps/ loadNewsEng.do?pSecId=6 (accessed on 7 January 2020).

50. MoA. National Agricultural Sector Strategy (2017-2022) "Resilience and Sustainable Development"; MoA: Ramallah, Palestine, 2016; p. 59.

51. Nofal, I. Personal Communication; Ministry of Agriculture: Ramallah, Palestine, 2019.

52. Gould, J.; Nissen-Petersen, E. Rainwater Catchment Systems for Domestic Supply: Design, Construction and Implementation; Intermediate Technology Publications: London, UK, 1999; p. 320, ISBN 978-1-85339-456-0.

53. Shadeed, S.; Almasri, M. Application of GIS-based SCS-CN method in West Bank catchments, Palestine. Water Sci. Eng. 2010, 3, 1-13.

54. Saaty, T.L. The Analytic Hierarchy Process: Planning, Priority Setting, Resource Allocation; McGraw-Hill International Book Co: New York, NY, USA, 1980; ISBN 13-978-0070543713.

55. Saaty, T.L. Managing Forest Ecosystems. In Fundamentals of decision making with the analytic hierarchy process. In The Analytic Hierarchy Process in Natural Resource and Environmental Decision Making, 1st ed.; Schmoldt, D.L., Kangas, J., Mendoza, G.A., Pesonen, M., Eds.; Springer: Dordrecht, The Netherlands, 2000; Volume 3, p. 307, ISBN 978-94-015-9799-9.

56. Store, R.; Jokimäki, J. A GIS-based multi-scale approach to habitat suitability modeling. Ecol. Model. 2003, 169, 1-15. [CrossRef]

57. Malczewski, J. GIS and Multicriteria Decision Analysis; John Wiley \& Sons Inc.: New York, NY, USA, 1999; p. 408, ISBN 978-0-471-32944-2.

(C) 2020 by the authors. Licensee MDPI, Basel, Switzerland. This article is an open access article distributed under the terms and conditions of the Creative Commons Attribution (CC BY) license (http://creativecommons.org/licenses/by/4.0/). 